JAMP: Jurnal Adminitrasi dan Manajemen Pendidikan

Volume 1 Nomor 2 Juni 2018, Hal : 124-131

Tersedia Online di http://journal2.um.ac.id/index.php/jamp/

ISSN $x x x x-x x x x$ (online)

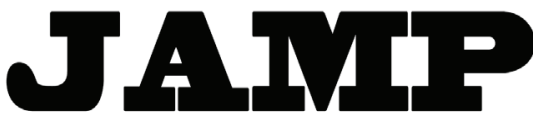

JURNAL ADMINISTRASI DAN MANAJEMEN PENDIDIKAN

\title{
HUBUNGAN PELAKSANAAN SISTEM INFORMASI MANAJEMEN BERBASIS KOMPUTER DAN KEEFEKTIFAN KINERJA PNS DI PERGURUAN TINGGI
}

\author{
Maulana Amirul Adha \\ Mustiningsih \\ Maisyaroh \\ E-mail: amirulmaulana1013@gmail.com \\ Universitas Negeri Malang, Jalan Semarang No.5 Malang
}

\begin{abstract}
This study aims to, (1) find out the implementation of computer-based management information system (MIS) in faculties of State University of Malang (UM); (2) to know the effectiveness of the civil servant's performance in faculties of State University of Malang; and (3) to know the correlation of implementation of computer-based management system and the effectiveness of civil servant's performance in faculties of State University of Malang. This research uses quantitative approach with descriptive correlational research design. The instrument of this research is a questionnaire with civil servant respondents in faculties of State University of Malang. The analysis technique used in this research is descriptive analysis and correlation. The results of this study indicate: (1) the level of implementation of computer-based management information system consisting of hardware, software, database, procedure, telecommunication network and brainware in faculties of State University of Malang is good; (2) the level of effectiveness of civil servant's performance consisting of work quantity, work quality, and working time utilization in faculties of State University of Malang are high; and (3) there is a significant positive correlation between the implementation of computer-based management information system and the effectiveness of civil servant's performance in faculties of State University of Malang.
\end{abstract}

Keywords : management information system, effectiveness of performance, civil servant, higher education

\begin{abstract}
Abstrak : Penelitian ini bertujuan untuk, (1) mengetahui pelaksanaan sistem informasi manajemen (SIM) berbasis komputer yang ada di fakultas-fakultas lingkungan Universitas Negeri Malang (UM); (2) mengetahui keefektifan kinerja PNS di fakultas-fakultas lingkungan UM; dan (3) mengetahui hubungan pelaksanaan SIM berbasis komputer dan keefektifan kinerja PNS di fakultas-fakultas lingkungan UM. Penelitian ini menggunakan pendekatan kuantitatif dengan rancangan penelitian bersifat deskriptif korelasional. Instrumen penelitian ini yakni angket dengan responden PNS di fakultas-fakultas lingkungan UM. Teknik analisis yang digunakan dalam penelitian ini ialah analisis deskriptif dan korelasi. Hasil penelitian ini menunjukkan: (1) tingkat pelaksanaan SIM berbasis komputer yang terdiri atas hardware, software, database, prosedur, jaringan telekomunikasi dan brainware di fakultas-fakultas lingkungan UM tergolong baik; (2) tingkat keefektifan kinerja PNS yang terdiri atas kuantitas kerja, kualitas kerja, dan pemanfaatan waktu kerja di fakultas-fakultas lingkungan UM tergolong tinggi; dan (3) ada hubungan positif yang signifikan antara pelaksanaan SIM berbasis komputer dan keefektifan kinerja PNS di fakultas-fakultas lingkungan UM.
\end{abstract}

Kata kunci: Sistem informasi manajemen, keefektifan kinerja, PNS, perguruan tinggi 
Perkembangan pesat ilmu pengetahuan dan teknologi menimbulkan pengaruh terhadap kegiatan organisasi secara keseluruhan. Operasional manajemen dalam pelaksanaannya informasi adalah aset yang sangat penting. Hal ini sebagaimana dikemukakan oleh Kanter (dalam Darmawan dan fauzi, 2015:9), yang menyatakan "Information is the stuff of paper work system just as material is the stuff of production system", oleh karenanya informasi harus dikelola dengan baik. Informasi ialah hasil proses pengolahan data yang disajikan dengan berbagai bentuk supaya bisa memberi makna atau arti tertentu pada penggunanya, oleh karenanya ketergantungan manusia atau organisasi terhadap informasi sangat besar, maka dari itu peningkatan kualitas informasi harus dilakukan. Mc leod (dalam Darmawan \& Fauzi, 2015:2) menyatakan informasi yang baik harus mempunyai kriteria tepat waktu, akurat, lengkap serta relevan.

Kebutuhan data dan informasi dalam suatu organisasi sangat penting agar tujuan organisasi dapat dicapai. Pemenuhan pengelolaan informasi yang baik harus ditunjang dengan alat bantu berkemampuan tinggi serta akurat dalam mengolah data. Perkembangan teknologi yang kian canggih, SIM dalam suatu organisasi sudah didukung dengan bantuan alat serta perangkat komputer. Menurut Teguh (2001:54) suatu jaringan dengan bantuan perangkat komputer yang memberi kebutuhan bagi para penggunanya yang terdiri atas sistem yang saling berhubungan disebut SIM berbasis komputer. Penggunaan komputer dalam menyelesaikan pekerjaan yang dilakukan menjadi lebih cepat serta efisien.

Operasional manajemen dalam pelaksanaannya informasi adalah aset yang sangat penting. Hal ini sebagaimana dikemukakan oleh Kanter (dalam Darmawan dan fauzi, 2015:9), yang menyatakan "Information is the stuff of paper work system just as material is the stuff of production system", oleh karenanya informasi harus dikelola dengan baik. Informasi ialah hasil proses pengolahan data yang disajikan dengan berbagai bentuk supaya bisa memberi makna atau arti tertentu pada penggunanya, oleh karenanya ketergantungan manusia atau organisasi terhadap informasi sangat besar, maka dari itu peningkatan kualitas informasi harus dilakukan. Mc leod (dalam Darmawan \& Fauzi, 2015:2) menyatakan informasi yang baik harus mempunyai kriteria tepat waktu, akurat, lengkap serta relevan.

Berdasarkan hasil studi lapangan yang peneliti lakukan di salah satu Fakultas di lingkungan Universitas Negeri Malang (UM) yaitu di Fakultas Ilmu Pendidikan (FIP) UM, Pegawai FIP UM telah melaksanakan SIM berbasis komputer dengan kualifikasi variasi yang berbeda-beda. Pelaksanaan SIM berbasis komputer di lingkungan FIP UM memberikan manfaat bagi pengguna informasi, tetapi tidak semua pegawai di FIP UM memiliki kualifikasi yang sama dalam hal pelaksanaan SIM berbasis komputer. Penggunaan SIM berbasis elektronik atau komputer juga dijamin oleh Undang-Undang RI Nomor 11 Tahun 2011 Tentang Informasi dan Transaksi Elektronik Pasal 1 Ayat 6 yang berbunyi "Penyelenggaraan Sistem Elektronik adalah pemanfaatan sistem elektronik oleh penyelenggara negara, orang, badan usaha dan/ atau masyarakat". Pegawai dalam meningkatkan kinerjanya secara teoritis, dibantu dengan penerapan SIM berbasis komputer pada suatu organisasi yang memberikan banyak kemudahan. Suatu sistem untuk mengelola informasi dalam rangka pengambilan keputusan dapat disebut SIM. Masukan informasi yang tepat adalah salah satu yang mempengaruhi pengambilan keputusan yang tepat.

Kinerja yang baik salah satu ukurannya ialah keefektifan kinerja para pegawai. Keefektifan kinerja pegawai menunjukkan adanya ketepatan dalam melaksanakan pekerjaan dengan dukungan data yang valid. Menurut Kusdi (2009:94) keefektifan kinerja yaitu kemampuan organisasi dalam mencapai sasaran (jangka pendek) serta tujuan (jangka panjang) sesuai dengan yang direncanakan, penentuan sasaran-sasaran serta tujuan-tujuan itu menggambarkan komponen strategis, ketertarikan personal penilai, dan tahap pertumbuhan organisasi. Definisi diatas menjelaskan bahwa ketercapaian sasaran dan tujuan dapat tercapai apabila kinerja pegawai berjalan dengan efektif.

Data kelembagaan yang valid bisa didapatkan ketika data yang ada diolah serta disalurkan menggunakan sistem yang tepat dan jelas. Pelaksanaan SIM berbasis komputer dalam mendukung keefektifan kinerja personil organisasi, diperlukan dukungan beberapa komponen secara terarah. Menurut Bubel dkk (2015:199) "management of a higher education institution can be examined from various angles, in a variety of aspects, both in terms of managing knowledge and information and managing information technology and system". Pengelolaan institusi pendidikan tinggi dapat dilihat 
dari berbagai aspek salah satunya ialah bagaimana institusi tersebut mengelola teknologi sistem informasi, artinya penting bagi institusi pendidikan tinggi dalam hal ini Universitas Negeri Malang agar dapat mengelola informasi dengan sebaik-baiknya. Memeroleh informasi memerlukan data yang diproses oleh unit pengolah. Darmawan dan Fauzi (2015:2) mengemukakan informasi ialah hasil dari pemprosesan data, tetapi tidak semua hasil pemprosesan data dapat menjadi informasi, hasil pemprosesan data yang tidak memberi makna atau arti dan tidak berguna bagi penggunanya tidak bisa disebut informasi. Penjelasan pendapat ahli diatas mengenai informasi yang harus diperhatikan adalah (1) informasi ialah hasil pemprosesan data, (2) memberi makna dan arti, dan (3) bermanfaat dalam meningkatkan kepastian. Pengelolaan sistem informasi yang baik akan dapat memenuhi kriteria informasi yang berkualitas. Temuan sebelumnya yakni Sujata, Noak dan Supriliyani (2016) ditemukan bahwa SIM berbasis komputer berpengaruh positif serta signifikan terhadap kinerja pegawai. Penelitian terdahulu memfokuskan penelitiannya terhadap kinerja pegawai.

Universitas Negeri Malang sebagai organisasi yang besar dan melayani banyak orang, baik mahasiswa, dosen, alumni, maupun masyarakat sudah seharusnya UM memiliki fasilitas serta personil yang memadai dalam melaksanakan SIM berbasis komputer. Aplikasi SIM berbasis komputer memberikan pengaruh yang berarti bagi peningkatan keefektifan kinerja para pegawai, sebab SIM berbasis komputer dapat membantu memperoleh informasi serta penyelesaian tugas pegawai secara akurat serta cepat. Seperti yang dikemukakan oleh Darodjat (2015:375) bahwa salah satu manfaat utama dari perkembangan sistem informasi adalah peningkatan keefektifan.

\section{METODE}

Pendekatan kuantitatif dengan rancangan penelitian bersifat deskriptif korelasional digunakan dalam penelitian ini. Penelitian kuantitatif menurut Wiyono (2007:28) digunakan untuk memaparkan kejadian atau fenomena sesuai apa yang terjadi saat penelitian dilaksanakan. Penelitian ini bersifat deskriptif sebab bertujuan untuk mendapatkan gambaran mengenai variabel yang diteliti, bersifat korelasional sebab penelitian ini bertujuan untuk mengetahui ada tidaknya hubungan antara dua variabel atau lebih. Hubungan antar variabel dapat dilihat pada gambar 1.

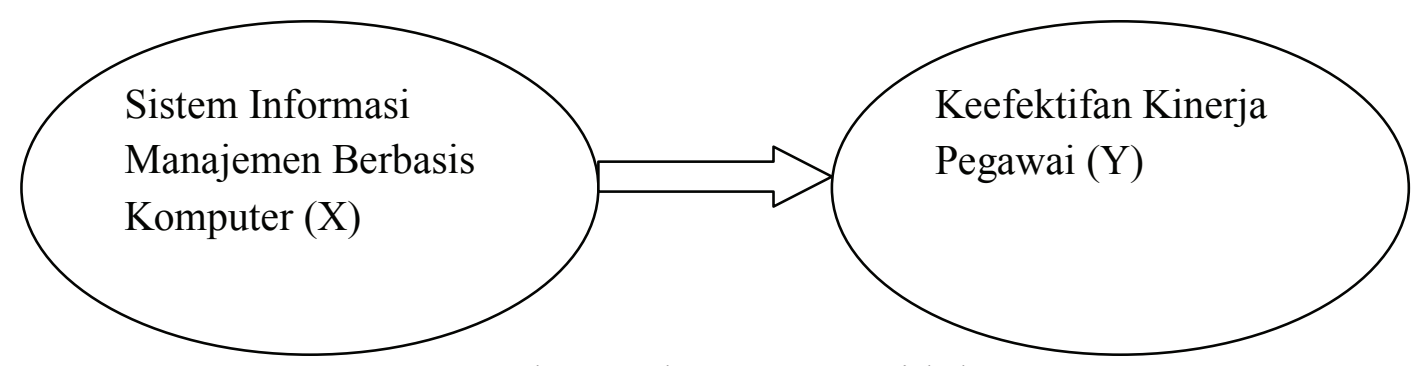

Gambar 1. Hubungan antar Variabel

Instrumen penelitian yang digunakan dalam penelitian ini adalah angket dengan responden pegawai di fakultas-fakultas lingkungan UM. Populasi dalam penelitian sejumlah 258 orang pegawai, kemudian pengambilan sampel menggunakan tehnik proportional random sampling dengan menggunakan rumus formula Slovin, diperoleh hasil sampel sejumlah 161 pegawai. Teknik analisis yang digunakan dalam penelitian ini ialah analisis deskriptif dan korelasi. Penelitian ini dalam melalakukan analisis data menggunakan bantuan Method of Successive Interval (MSI) dan Statistical Package for Social Science for windows versi 24.0.

\section{HASIL}

\section{Pelaksanaan SIM Berbasis Komputer}

Pelaksanaan SIM berbasis komputer di fakultas-fakultas lingkungan UM tergolong baik sebesar $75,16 \%$. Tergolong dalam kategori sedang sebesar $24,22 \%$. Kategori tidak baik sebesar $0,62 \%$. 
Berdasarkan analisis data diatas dapat disimpulkan, bahwa persentase tingkat pelaksanaan sistem informasi manajemen berbasis komputer di fakultas-fakultas lingkungan UM dalam kategori 'baik', yakni sebesar $75,16 \%$. Hasil penelitian tersebut merupakan kumpulan dari sub-variabel penelitian yang meliputi hardware (perangkat keras), software (perangkat lunak), database, prosedur, jaringan telekomunikasi, dan brainware (personil). Hasil masing-masing subvariabel dapat disajikan sebagai berikut.

Berdasarkan analisis data disimpulkan, bahwa persentase tingkat kualifikasi hardware di fakultasfakultas lingkungan UM dalam kategori 'baik', yakni sebesar 76,40\%, tingkat kualifikasi software di fakultas-fakultas lingkungan UM tergolong baik sebesar 75,78\%, tingkat kualifikasi database di fakultas-fakultas lingkungan UM tergolong baik sebesar 70,81\%, tingkat kualifikasi prosedur di fakultasfakultas lingkungan UM tergolong baik sebesar $75,78 \%$, kualifikasi jaringan telekomunikasi di fakultasfakultas lingkungan UM tergolong baik sebesar $66,46 \%$, dan kualifikasi brainware di fakultas-fakultas lingkungan UM tergolong baik sebesar 57,14\%.

\section{Keefektifan Kinerja Pegawai Negeri Sipil}

Keefektifan kinerja pegawai negeri sipil di fakultas-fakultas lingkungan UM tergolong tinggi sebesar $88,20 \%$. Tergolong dalam kategori sedang sebesar $11,80 \%$. Kategori rendah sebesar $0,00 \%$. Berdasarkan analisis data diatas dapat disimpulkan, bahwa persentase tingkat keefektifan kinerja pegawai negeri sipil di fakultas-fakultas lingkungan UM dalam kategori 'tinggi', yakni sebesar 88,20\%. Hasil penelitian tersebut merupakan kumpulan dari sub-variabel penelitian yang meliputi kuantitas kerja, kualitas kerja, dan pemanfaatan waktu. Hasil masing-masing subvariabel dapat disajikan sebagai berikut.

Berdasarkan analisis data disimpulkan, bahwa persentase tingkat kualifikasi kuantitas kerja pegawai negeri sipil di fakultas-fakultas lingkungan UM dalam kategori 'tinggi', yakni sebesar $60,25 \%$, kualifikasi kualitas kerja pegawai di fakultas-fakultas lingkungan UM tergolong tinggi sebesar $88,82 \%$,dan kualifikasi pemanfaatan waktu pegawai negeri sipil di fakultas-fakultas lingkungan UM tergolong tinggi sebesar $87,58 \%$.

\section{Hubungan Pelaksanaan SIM Berbasis Komputer dan Keefektifan Kinerja Pegawai Negeri Sipil}

Berdasarkan hasil perhitungan diperoleh rhitung sebesar 0,390 pada taraf signifikansi $5 \%$ atau 0,5 dengan tanda ** (dua bintang) pada analisis korelasi Product Moment Pearson dengan menggunakan SPSS 24.0 for windows dan jumlah sampel 161 orang pegawai. Berdasarkan hasil perhitungan diatas didapatkan pengujian hipotesis, Tabel 1.

Tabel 1 Pengujian Hipotesis

\begin{tabular}{llll}
\hline Hipotesis & Hasil Uji & Sign & Hasil Pengujian \\
\hline $\begin{array}{l}\text { h0: tidak ada hubungan antara pelaksanaan sistem } \\
\text { informasi manajemen berbasis komputer dan }\end{array}$ & $\mathbf{0 , 0 0 0}$ & $\mathbf{0 . 0 5 0}$ & h0 ditolak \\
keefektifan kinerja pegawai negeri sipil. & & & \\
\hline
\end{tabular}

Berdasarkan Tabel 1 dapat diketahui bahwa H0 ditolak, yang berarti Ha diterima artinya ada hubungan pelaksanaan SIM berbasis komputer dan keefektifan kinerja pegawai negeri sipil di fakultasfakultas lingkungan UM. Nilai hasil uji signifikansi berdasarkan pada Tabel 1 yang menunjukkan angka 0,000 artinya angka probabilitas $(\mathrm{SIG})<0,05$ ada hubungan antara kedua variabel yang signifikan. Hal ini menunjukan adanya hubungan yang signifikan antara dua variabel tersebut dan bersifat positif, yakni bila variabel SIM berbasis komputer besar, maka variabel keefektifan kinerja pegawai negeri sipil semakin besar pula. 


\section{PEMBAHASAN}

\section{Pelaksanaan SIM Berbasis Komputer}

Tingkat pelaksanaan SIM berbasis komputer di fakultas-fakultas lingkungan Universitas Negeri Malang yang tergolong baik, menunjukkan bahwa komputer dalam sistem informasi manajemen mampu menjadi alat bantu yang bermanfaat untuk memproses data, dapat menyerap input dan output, mempunyai kecepatan tinggi, ketelitian tinggi, dan dapat menyimpan perintah-perintah untuk menyelesaikan masalah. Pelaksanaan SIM yang baik akan memberikan keuntungan seperti yang dikemukakan oleh Amsyah (2003:138) yakni: (a) efisiensi lebih tinggi; (b) pengawasan bisa dilaksanakan dengan tertib; (c) biaya lebih rendah; (d) kesalahan lebih sedikit; (e) memudahkan perencanaan, pengorganisasian kegiatan operasional dan distribusi; (f) kebijakan berbasis informasi lebih mudah dibuat; (g) petugas ketatausahaan dapat dikurangi penggunaannya.

Hasil pengolahan data tentang perangkat keras (hardware) menunjukkan, bahwa tingkat kualifikasi hardware di fakultas-fakultas lingkungan Universitas Negeri Malang tergolong baik. Hal ini dibuktikan dari 123 responden atau sebesar 76,40\% menyatakan kualifikasi hardware dalam kategori baik. Ini mengandung arti bahwa perangkat keras, baik alat masukan, CPU, maupun alat keluaran yang disediakan oleh institusi telah menunjang atau mengerjakan fungsi-fungsinya dalam pelaksanaan sistem informasi manajemen berbasis komputer di fakultas-fakultas lingkungan Universitas Negeri Malang. Hal ini sependapat dengan Amsyah (2003:163) yang menyatakan bahwa hardware dimanfaatkan untuk melaksanakan tugas-tugas penyimpan data, pemasukan data, penghitungan, pengawasan, penyimpanan, serta pengeluaran (presentasi atau peragaan) hasil. Perangkat keras merupakan satu sub variabel yang paling konkrit, artinya wujudnya berupa segala fasilitas yang dapat terlihat.

Hasil pengolahan data tentang perangkat lunak (software) menunjukkan, bahwa tingkat kualifikasi software di fakultas-fakultas lingkungan Universitas Negeri Malang tergolong baik. Hal ini dibuktikan dari 122 responden atau sebesar 75,78\% menyatakan kualifikasi software dalam kategori baik. Ini mengandung arti bahwa perangkat lunak yang disediakan oleh institusi berupa system software serta application software mampu menunjang pelaksanaan sistem informasi manajemen bersasis komputer di fakultas-fakultas lingkungan Universitas Negeri Malang. Hal ini sependapat dengan Darmawan dan Fauzi (2015:73) perangkat lunak dapat dibagi menjadi 2 jenis berdasarkan fungsinya yaitu perangkat lunak sistem (system software) dan perangkat lunak aplikasi (application software). Perangkat lunak sistem berfungsi untuk mengendalikan sistem yang ada pada komputer. Sistem operasi yang digunakan adalah sistem operasi yang dibuat oleh Microsoft yakni Microsoft Windows. Perangkat lunak aplikasi berfungsi membantu menyelesaikan masalah yang bersifat relatif, perangkat lunak aplikasi yakni Presentasi, Browser, Pengolah kata (Word Processor), Spreedsheet, Statistik, dan Utility.

Hasil pengolahan data tentang database menunjukkan, bahwa tingkat kualifikasi database di fakultasfakultas lingkungan Universitas Negeri Malang tergolong baik. Hal ini dibuktikan dari 114 responden atau sebesar 70,81\% menyatakan kualifikasi database dalam kategori baik. Ini mengandung arti bahwa kegiatan database, sudah terintegrasi dan berjalan dengan baik dalam menunjang pelaksanaan sistem informasi manajemen berbasis komputer di fakultas-fakultas lingkungan Universitas Negeri Malang. Database adalah kumpulan informasi yang disimpan dalam komputer dengan sistematik sehingga dapat diperiksa menggunakan suatu program untuk memeroleh informasi dari basis data tersebut (Darmawan dan Fauzi, 2015:101). Hal ini menunjukkan bahwa dengan kualifikasi database di fakultas-fakultas lingkungan Universitas Negeri Malang yang tergolong baik database dapat dimanfaatkan untuk menyimpan informasi atau data integrasi dengan baik dalam komputer.

Hasil pengolahan data tentang prosedur menunjukkan, bahwa tingkat kualifikasi prosedur di fakultas-fakultas lingkungan Universitas Negeri Malang tergolong baik. Hal ini dibuktikan dari 122 responden atau sebesar $75,78 \%$ menyatakan kualifikasi prosedur dalam kategori baik. Ini mengandung arti bahwa prosedur yang disediakan oleh institusi telah menunjang dalam menunjang pelaksanaan sistem informasi manajemen berbasis komputer di fakultas-fakultas lingkungan UM. Hal ini senada dengan yang dikemukakan Sutabri (2016:87) prosedur merupakan komponen fisik karena prosedur disediakan dalam bentuk fisik seperti buku panduan dan intruksi. Hal ini menunjukkan bahwa dengan 
kualifikasi prosedur di fakultas-fakultas lingkungan Universitas Negeri Malang yang tergolong baik prosedur yang telah disediakan oleh institusi mampu membantu pegawai dalam melaksanakan kegiatan SIM berbasis komputer.

Hasil pengolahan data tentang jaringan telekomunikasi menunjukkan, bahwa tingkat kualifikasi jaringan telekomunikasi di fakultas-fakultas lingkungan Universitas Negeri Malang tergolong baik. Hal ini dibuktikan dari 107 responden atau sebesar $66,46 \%$ menyatakan kualifikasi jaringan telekomunikasi dalam kategori baik. Ini mengandung arti bahwa jaringan telekomunikasi baik komputer sebagai host, saluran komunikasi dan software telekomunikasi mampu menunjang kegiatan sistem informasi manajemen berbasis komputer di fakultas-fakultas lingkungan UM. Hal ini senada dengan yang dikemukakan Susanto (2002:60) komponen dalam jaringan telekomunikasi yakni komputer, saluran komunikasi dan software telekomunikasi. Hal ini menunjukkan bahwa dengan kualifikasi jaringan telekomunikasi di fakultas-fakultas lingkungan Universitas Negeri Malang yang tergolong baik jaringan telekomunikasi yang tersusun dari kumpulan hardware dan software mampu mengomunikasikan berbagai macam informasi dari satu lokasi ke lokasi yang lain dalam mendukung kegiatan sistem informasi manajemen berbasis komputer di fakultas-fakultas lingkungan Universitas Negeri Malang.

Hasil pengolahan data tentang personil (brainware) menunjukkan, bahwa tingkat kualifikasi brainware di fakultas-fakultas lingkungan Universitas Negeri Malang tergolong baik. Hal ini dibuktikan dari 92 responden atau sebesar 57,14\% menyatakan kualifikasi brainware dalam kategori baik. Ini mengandung arti bahwa personil baik operator komputer, analis sistem, programmer, personel data entry, dan manajer sistem informasi mampu menunjang pelaksanaan sistem informasi manajemen berbasis komputer di fakultas-fakultas lingkungan Universitas Negeri Malang. Personil merupakan satu bagian terpenting dalam pelaksanaan sistem informasi manajemen. Berdasarkan hasil penelitian yang menunjukkan sub variabel personil dalam kualifikasi baik, artinya personil fakultas-fakultas di lingkungan Universitas Negeri Malang mampu melaksanakan tugas-tugasnya dalam kegiatan sistem informasi manajemen berbasis komputer dengan baik sebagaimana yang dikemukakan Sutabri (2016:87) tugas personil dalam sistem informasi manajemen berbasis komputer: (a) operator komputer, memiliki tugas menjalankan langsung sistem komputer; (b) analis sistem, memiliki tugas mempelajari serta menganalisis permasalahan yang timbul pada organisasi, untuk pengembangan atau pembangunan sistem informasi; (c) programmer, merupakan staf yang menangani pembuatan program dengan menggunakan bahasa pemrograman atau package program yang dikuasai.; (d) personil data entry, memiliki tugas menginput data atau merekam data ke dalam komputer sesuai dengan perintah yang disediakan; dan (e) manajer sistem informasi (electronic data processing/EDP), adalah jabatan tertinggi di bidang SIM berbasis komputer, dalam rangka mengerjakan tugasnya, manajer harus bisa menyiapkan rencana jangka panjang ataupun rencana jangka pendek serta menyiapkan anggaran setiap tahun untuk kebutuhan pemeliharaan hardware, software, pelatihan, pemeliharaan, serta lain-lain.

\section{Keefektifan Kinerja Pegawai Negeri Sipil}

Tingkat keefektifan kinerja pegawai negeri sipil di fakultas-fakultas lingkungan Universitas Negeri Malang yang tergolong tinggi, menunjukkan bahwa pegawai negeri sipil di fakultas-fakultas lingkungan Universitas Negeri Malang dapat menyelesaikan tugas dan tanggungjawabnya secara cepat dan tepat dilihat dari segi kuantitas dan kualitas senada dengan pendapat Mangkunegara (2007:67) kinerja (prestasi kerja) ialah output kerja dilihat dari kuantitas serta kualitas yang dicapai pegawai dalam rangka menjalankan fungsi dan tanggung jawabnya. Berdasarkan hasil penelitian yang dilaksanakan, disimpulkan bahwa keefektifan kinerja pegawai negeri sipil di fakultas-fakultas lingkungan Universitas Negeri Malang berjalan dengan baik dan benar, sehingga pencapaian tujuan organisasi tercapai sesuai yang direncanakan.

Hasil pengolahan data tentang kuantitas kerja menunjukkan, bahwa tingkat kualifikasi kuantitas kerja pegawai negeri sipil di fakultas-fakultas lingkungan Universitas Negeri Malang tergolong tinggi. Hal ini dibuktikan dari 97 responden atau sebesar 60,25\% menyatakan kualifikasi kuantitas kerja pegawai negeri sipil di fakultas-fakultas lingkungan Universitas Negeri Malang dalam kategori tinggi. Ini mengandung arti bahwa pegawai negeri sipil di fakultas-fakultas lingkungan Universitas Negeri 
Malang mampu menghasilkan hasil kerja sesuai dengan beban kerja yang didapatkan walaupun dengan volume pekerjaan yang besar hal ini sesuai dengan yang diungkapkan Hasibuan (2003:105) Kuantitas kerja adalah banyaknya output kerja yang diselesaikan dibawah kondisi normal. Banyaknya output kerja atau volume kerja dapat dinilai dari beban kerja serta jumlah output (hasil pekerjaan) pegawai negeri sipil di fakultas-fakultas lingkungan Universitas Negeri Malang. Hal ini dikarenakan pegawai mampu menentukan dan mengatur prioritas pekerjaan sesuai dengan beban kerja yang didapatkan sehingga mampu menyelesaikan pekerjaan sesuai dengan beban kerja dan jumlah output pekerjaan yang besar.

Hasil pengolahan data tentang kualitas kerja menunjukkan, bahwa tingkat kualifikasi kualitas kerja pegawai negeri sipil di fakultas-fakultas lingkungan Universitas Negeri Malang tergolong tinggi. Hal ini dibuktikan dari 143 responden atau sebesar 88,82\% menyatakan kualifikasi kualitas kerja pegawai negeri sipil dalam kategori tinggi. Hal ini menggambarkan jika pegawai negeri sipil di fakultas-fakultas lingkungan Universitas Negeri Malang mampu menghasilkan hasil kerja yang berkualitas dilihat dari kerapian hasil kerja, ketepatan hasil kerja, ketelitian hasil kerja, dan keterkaitan hasil hal ini sesuai dengan yang diungkapkan Hasibuan (2003:105) kualitas kerja ialah perilaku yang ditunjukkan oleh pegawai yang berupa hasil kerja (output) dalam bentuk ketepatan, kerapian, ketelitian, serta keterkaitan hasil dengan tidak meninggalkan volume pekerjaan dalam melaksanakan tugasnya. Pegawai negeri sipil di fakultas-fakultas lingkungan Universitas Negeri Malang memperhatikan kualitas hasil kerja yang dikerjakan. Hal ini dikarenakan pegawai mengutamakan kecermatan dalam melaksanakan pekerjaan sehingga mampu menyelesaikan pekerjaan yang berkualitas tanpa mengabaikan volume pekerjaan.

Hasil pengolahan data tentang pemanfaatan waktu menunjukkan, bahwa tingkat kualifikasi pemanfaatan waktu kerja pegawai negeri sipil di fakultas-fakultas lingkungan Universitas Negeri Malang tergolong tinggi. Hal ini dibuktikan dari 141 responden atau sebesar $87,58 \%$ menyatakan kualifikasi pemanfaatan waktu kerja pegawai negeri sipil dalam kategori tinggi. Hal ini menggambarkan jika pegawai negeri sipil di fakultas-fakultas lingkungan Universitas Negeri Malang mampu menyelesaikan tugas sesuai dengan waktu pekerjaan yang ditetapkan hal ini sesuai dengan yang diungkapkan Hasibuan (2003:105) pemanfaatan waktu ialah pengggunaan waktu kerja yang disesuaikan dengan kebijaksanaan organisasi bersangkutan supaya pekerjaan terselesaikan tepat pada waktunya. Pegawai negeri sipil di fakultas-fakultas lingkungan Universitas Negeri Malang dalam melaksanakan pekerjaan memperhatikan beberapa hal yakni ketepatan waktu penyelesaian, disiplin waktu dan penggunaan waktu. Waktu penyelesaian, disiplin waktu, dan penggunaan waktu kerja merupakan hal yang penting dalam melaksanakan pekerjaan, hal ini dikarenakan tuntutan pekerjaan yang harus diselesaikan sesuai dengan waktu yang ditetapkan. Pegawai yang tidak memperhatikan ke tiga hal tersebut pasti akan kesulitan dalam menyelesaikan pekerjaan sesuai dengan deadline atau waktu yang ditetapkan.

\section{Hubungan Pelaksanaan Sistem Informasi Manamen Berbasis Komputer dan Keefektifan Kinerja PNS}

Hasil penelitian yang dijabarkan menunjukkan keefektifan kinerja pegawai negeri sipil dipengaruhi oleh variabel lain menurut Pasolong (2007:4) keefektifan berasal dari kata efek, istilah ini dapat dianggap sebagai hubungan sebab akibat. Keefektifan bisa dilihat sebagai suatu sebab dari variabel lain, dalam hal ini keefektifan kinerja pegawai negeri sipil di fakultas-fakultas lingkungan Universitas Negeri Malang dipengaruhi oleh SIM berbasis komputer. Berdasarkan hasil penelitian yang didapatkan pelaksanaan SIM berbasis komputer memberikan pengaruh yang berarti untuk peningkatan keefektifan kinerja para pegawai di fakultas-fakultas lingkungan Universitas Negeri Malang, karena SIM berbasis komputer dapat membantu memeroleh informasi serta penyelesaian tugas pegawai secara akurat serta cepat. Seperti yang dikemukakan oleh Darodjat (2015:375) bahwa salah satu manfaat utama dari perkembangan sistem informasi adalah peningkatan keefektifan. Peningkatan kinerja pegawai pasti dibutuhkan untuk mencapai tujuan yang diinginkan tiap organisasi. Tiap pegawai sepatutnya dibimbing untuk meningkatkan keefektifan kinerja mereka melalui proses usaha secara maksimal salah satunya dengan SIM berbasis komputer, sehingga pemberdayaan pegawai lebih mendukung keberhasilan organisasi. 


\section{KESIMPULAN DAN SARAN}

\section{Kesimpulan}

Kualifikasi tingkat pelaksanaan SIM berbasis komputer yang terdiri atas hardware, software, database, prosedur, jaringan telekomunikasi dan brainware di fakultas-fakultas lingkungan Universitas Negeri Malang tergolong baik. Tingkat keefektifan kinerja pegawai negeri sipil yang terdiri atas kuantitas kerja, kualitas kerja, pemanfaatan waktu kerja di fakultas-fakultas lingkungan Universitas Negeri Malang tergolong tinggi. Hasil penelitian menunjukkan, ada hubungan positif yang signifikan antara pelaksanaan SIM berbasis komputer dan keefektifan kinerja pegawai negeri sipil di fakultasfakultas lingkungan Universitas Negeri Malang.

\section{Saran}

Berdasarkan kesimpulan, peneliti memberikan beberapa saran yakni, (1) Rektor UM, hendaknya pimpinan mengadakan pelatihan kepada pegawai mengenai SIM berbasis komputer dalam rangka meningkatkan keefektifan kinerja pegawai; (2) Dekan Fakultas-Fakultas lingkungan UM, hendaknya pimpinan di tiap fakultas mengadakan evaluasi kepada para pegawai guna mendukung peningkatan keefektifan kinerja pegawai; (3) Kepala Bagian Tata Usaha Fakultas-Fakultas lingkungan UM, hendaknya pimpinan dapat meningkatkan kinerja seperti melakukan pengawasan dan pengendalian pelaksanaan sistem informasi manajemen berbasis komputer yang dilakukan pegawai guna mendukung peningkatan keefektifan kinerja pegawai; (4) Pegawai Fakultas-Fakultas lingkungan UM, hendaknya pegawai dapat meningkatkan dan menyesuaikan kemampuan dengan perkembangan zaman yang memasuki era komputerisasi dalam rangka pelaksanaan SIM berbasis komputer dan peningkatan keefektifan kinerja pegawai; (5) Ketua Jurusan Administrasi Pendidikan, hendaknya dapat memberikan gambaran bahwa dengan pelaksanaan SIM berbasis komputer dapat meningkatkan keefektifan kinerja pegawai; dan (5) Peneliti Lain, hendaknya dapat mengembangkan penelitian ini dengan menemukan permasalahan atau kendala yang dialami dalam pelaksanaan SIM berbasis komputer serta dapat mencari solusi permasalahan tersebut.

\section{DAFTAR RUJUKAN}

Amsyah, Z. 2003. Manajemen Sistem Informasi. Jakarta : PT. Gramedia Pustaka Utama.

Bubel, D., Turek, I., Cichon, S. 2015. Multidimensional Management of a Higher Education Institution. International Journal of Arts and Sciences. 08(02), 199-213. Dari https://search.proquest.com/docview/1677217395/ fullte xtPDF/4EF1D824A7E04DA9PQ/1?accountid=38628.

Darmawan, D. \& Fauzi, K. N. 2015. Sistem Informasi Manajemen. Bandung: PT Remaja Rosdakarya.

Darodjat, T. A. 2015. Konsep-Konsep Dasar Manajemen Personalia Masa Kini. Bandung: PT Refika Aditama.

Hasibuan, M. S.P. 2003. Manajemen : Dasar, Pengertian, dan Masalah (Edisi Revisi). Jakarta : Bumi Aksara.

Kusdi. 2009. Teori Organisasi dan Administrasi. Jakarta: Selamba Humanika.

Mangkunegara, A. P. 2007. ManajemenSumberDayaManusia Perusahaan. Bandung: PT. RemajaRosdakarya. Pasolong, H. 2007. Teori Administasi Publik. Bandung: Alfabeta.

Sujata, P. P. A., Noak, P. A. \&Supriliyani, N. W. 2016. Pengaruh Sistem Informasi Manajemen Berbasis Komputer Terhadap Kinerja Pegawai Pada Koperasi Pegawai Negeri (KPN) Bina Sejahtera Kabupaten Badung Tahun 2016. Jurnal Citizen Charter, (Online), 1 (1), (http://id.portalgaruda.org/ article. php? article $=458675 \& \mathrm{val}=6121)$, diakses tanggal 28 September 2016.

Susanto, A. 2002. Sistem Informasi Manajemen : Konsep dan Pengembangannya. Bandung: Lingga Jaya.

Sutabri, T. 2016. Sistem Informasi Manajemen (edisi revisi). Yogyakarta: Andi.

Teguh, H. 2001. Sistem Informasi Manajemen. Terjemahan McLeod, R. Jr. 1998. Jakarta: PT. Prenhallindo.

Undang-Undang Republik Indonesia Nomor. 11 Tahun 2011 tentang Informasi dan TransaksiElektronik. Arsip Nasional Republik Indonesia. (Online), (http://www.anri.go.id/assets/ download/97UU-Nomor-11-Tahun2008-Tentang-Informasi-dan-Transaksi-Elektronik.pdf), diakses 13 Februari 2017.

Wiyono, B. B. 2007. Metodologi Penelitian (Pendekatan Kuantitatif, Kualitatif, dan Action Research) (Burhannuddin, Ed.). Malang: Fakultas Ilmu Pendidikan Universitas Negeri Malang. 